\title{
The correlation between students' grammar mastery and writing ability in descriptive text of the first grade students in MAN 1 Bandar Lampung
}

\author{
Inanda Narvika ${ }^{1}$, Dedy Supriyadi ${ }^{2}$, Rafista Deviyanti $^{\mathbf{3}}$ \\ Universitas Lampung, Jl. Prof. Dr. Soemantri Brojonegoro No.1 Bandar Lampung, Indonesia ${ }^{1,2,3}$ \\ ${ }^{1}$ Correspondence: inarvika31@gmail.com
}

\begin{abstract}
The objectives of the study were to find out the correlation between students' grammar mastery and writing ability and to find out what aspect of writing has the most correlation on students' grammar mastery. This research used quantitative approach. The subject of the research was the first grade students of MAN 1 Bandar Lampung. It consisted of thirteen classes; the total number of population was 439 students. By using sample random sampling, the sample of this research was 40 students taken from twelve classes ( 3 and 4 students in each class). A set of the grammar test in the form of multiple choices was used to measure students' grammar mastery and writing test was used to measure students' writing ability. Pearson Product Moment Correlation in SPSS 25.0 for windows was applied in this research to analyze the data. The result indicated that there was a correlation between students' grammar mastery and their writing ability since the significant value was 0.730 resided between $0.600-0.800$, which means the strength is high correlation. The data indicated that Sig. (2- tailed) $=0.00$ which was lower than 0.05 . This suggests that a student who has high scores in grammar mastery, she or he also get a good score in writing. It was assumed that language use was the aspect of writing has the most correlation on students' grammar mastery because; it was found that during the writing test, the students showed various errors, such as using incorrect tenses and unstructured sentences. Thus, it was suggested for teacher should explain more about grammar before teaching writing. From the research findings, it can be concluded that there was a positive correlation between students' grammar mastery and writing ability in descriptive text and language use was the aspect of writing that most correlated with grammar mastery.
\end{abstract}

Keywords: correlation, grammar, writing, aspects of writing.

\section{INTRODUCTION}

As a productive skill, writing is considered to be the most complex language skill to be learnt. As stated by Richards and Renandya (2002) on their book that writing is the most difficult skill for second language students to be mastered. It is because writers are required to have a lot of ideas and concentration in constructing writing. However, the difficulty is not only in generating and managing ideas, but also changing these ideas into readable text (Alameddine \& Mirza, 2016). In writing, the writers do not only need ideas but also skills to write their ideas into written form so that the reader can understand what is meant by the writer. Even tough writing is difficult to be mastered, students should have writing skill because writing is an important role in learning process to deliver their ideas. According to Walsh (2010) in (Klimova, 2012), writing is an important skill for students to learn because it is used in education and the workplace extensively. Writing can be a means for everyone to communicate and inform the information to others as a writer and reader. By mastering written English, students can communicate with people around the world. In short, students need understanding and mastery in writing skill.

In addition, writing is considered as a cognitive skill which combines knowledge and understanding with practice in language use. Language skills and language components are related to each other, so they cannot be separated. Therefore, we can find the language components in language skills 
(Andini et al., 2017). In writing, the used language components are grammar, vocabulary, pronunciation and punctuation. Furthermore, this research indicates that writing ability is as language skill and grammar mastery is as language component. It means that writing and grammar are related to each other.

According to (Brown, 1994), grammar is a system of rules that governs the conventional arrangement and relationship of words in a sentence. Hence, it is useful for students to know how to combine words to write meaningful sentences. Furthermore, the importance of using grammar in writing is stated by Frodesen and Eyring (2000) in (Fatemi, 2008), the focus on form (grammar), meaning and use in composition can help students to develop and enrich the linguistic resources needed to express ideas effectively. From the statement, it can be said grammar can help students to increase their writing in delivering ideas.

Furthermore, as one of the aspects that affect students' writing process to express their ideas, grammar plays an important role in order to form words into sentences appropriately. A research conducted by Adhiyatma and Jamiluddin (2015), Putri et al. (2016), Etfita (2019), Fatemi (2008), and Septiani (2014) found that the correlation between grammar mastery and writing ability were significant. It means, students' writing ability can be affected by their grammar mastery. Although several studies have revealed a positive correlation between grammar and writing, however more specific research on the grammar aspect needs to be conducted. Therefore, the researcher intends to analyze the correlation between aspects of writing and the use of language, especially grammar, namely mastery of grammar forms in descriptive text.

Additionally, based on the first grade syllabus of high school, the materials in learning grammar are pronouns, tenses, adjectives, verbs, nouns and adverbs. These materials are required to support students' understanding in writing. Furthermore, according to basic competences of curriculum 2013, students are expected to be able to write some texts in learning writing such as descriptive, recount and narrative texts. In this research, the researcher focuses on descriptive text. Descriptive text is a text which has function to describe an object such as a place, person, animal and thing. According to Gerot and Wignell (1994), descriptive text is a type of text that aims to provide information by describing particular things. This type of text will be used in this research because it mostly use of grammar such as simple present tense, noun phrase, action verb, to be present, and to be past.

Accordingly the background above, the writer is motivated to conduct an investigation on the correlation between grammar mastery and writing ability especially in descriptive text. The writer is intended to research about:

“The Correlation between Students' Grammar Mastery and Writing Ability in Descriptive Text of The First Grade Students in MAN 1 Bandar Lampung"

\section{METHODS}

This research used quantitative approach. The researcher used Correlation Research Design to answer the research question. There is no treatment in this research. By using simple random sampling, the researcher chose 40 students taken from twelve classes ( 3 and 4 students in each class) at MAN 1 Bandar Lampung. This research used grammar and writing test to collect the data.

In grammar test, the researcher used multiple choices test. There were 30 questions consisted of simple present tense, noun phrase, linking verb, to be present, and to be past. For writing test, the students were asked to describe about someone their love. In assessing students' writing ability, the 
researcher used the assessment suggested by Jacobs et al. (1981) such as content, organization, vocabulary, language use, and mechanics. Then, the scores of the students' grammar and writing scores were analyzed by using Pearson Product Moment to know the correlation.

\section{RESULTS AND DISCUSSIONS}

\section{Result}

This chapter describes a general description of data gained by the researcher during the research. The data were collected from the result of the students' grammar and writing test. The validity and reliability test had been conducted before the researcher administered the test. Before answering the research question of this study, the data description of this research has been obtained.

\section{The Result of Grammar Test}

In grammar test, the mean of students' grammar mastery (X) was 72.2. Among 40 students, the highest score of grammar test was 83 and it was achieved by three students. The lowest score was 60 and it was achieved by two students. There were four students who got 63 , five students got 67 , six students got 70, ten students got 73, six students got 77, and four students got 80 .

\section{The Result of Writing Test}

For the students' writing test, the researcher calculated the students' scores to get the final score (mean score of each student was based on the score from 2 raters which were the researcher and the teacher). The mean of students' writing ability (Y) was 75.7. The highest score of writing test was 85 and the lowest score was 66. There were ten students who got 66 to 70, eight students got 71 to 75 , sixteen students got 76 to 80 , and six students got 81 to 85 .

\section{The Correlation between Students' Grammar Mastery and Writing Ability}

As the data are shown below, the researcher got the result of each variable. This is the result of the correlation between students' grammar mastery and their writing ability.

Table 3.1 Analysis Result of Pearson Product Moment

\begin{tabular}{|llrr|}
\hline \multicolumn{4}{|c|}{ Correlations } \\
\hline & $\begin{array}{l}\text { Grammar } \\
\text { Mastery }\end{array}$ & \multicolumn{2}{c|}{ Writing } \\
& \multicolumn{3}{c|}{ Ability } \\
\hline Grammar & Pearson Correlation & 1 &, $730^{* *}$ \\
Mastery & Sig. (2-tailed) & &, 000 \\
& $\mathrm{~N}$ & 40 & 40 \\
\hline Writing Ability & Pearson Correlation &, $730^{* *}$ & 1 \\
& Sig. (2-tailed) &, 000 & \\
& $\mathrm{~N}$ & 40 & 40 \\
\hline **. Correlation is significant at the 0.01 level (2-tailed).
\end{tabular}

The table above showed that the correlation coefficient value of $r=0.730, N$. Sig $=0.000$ which means lower than level of significant 0.05 . It indicated that there was a significant correlation between the two variables. This research has a positive correlation because the variables had the same moderate score. If the subjects had low grammar scores, they also had low scores in writing descriptive. Conversely, if they had high grammar scores, they also had high scores in writing descriptive text. From the r number $(0.730)$, the researcher could use it to determine the strength of 
the correlation between the two variables. The number of 0.730 is in $0,600-0,800$, which means that the interpretation correlation between the two variables is high.

\section{Hypothesis Testing}

This researcher was done in collecting data and has got the result of the correlation. To answer the research problem, the writer had to measure whether the hypothesis was rejected or not. The writer has two hypotheses in this research, those are:

1. Null Hypothesis (H0): There is no correlation between students' grammar mastery and their writing ability.

2. Alternative Hypothesis (H1): There is correlation between students' grammar mastery and their writing ability.

To know the answer for the last hypothesis, the researcher used SPSS hypothesis testing based on the N. Sig (number of significance). From the result of correlation above (table 3.1), the value $\mathrm{r}=$ 0.841 and N. Sig $=0.000$. Before the writer concluded the answer, these are the theories of hypothesis based on SPSS calculation:

1. H0 accepted if N. Sig $>0.05(\alpha=5 \%)$

2. H1 accepted if N. Sig $<0.05(\alpha=5 \%)$

The result of the data showed that the significance was 0.000 (Level of significance 0.01 and 2 tailed) which clarified that $\mathrm{H} 0$ was rejected. The hypothesis testing concluded that N. Sig <5\%, where H1 was accepted. It means that both students' grammar mastery and their writing ability in descriptive text are correlated. Thus, it can be concluded that "There is a correlation between students' grammar mastery and writing ability in descriptive text", answered the research problem.

\section{The Result of Writing Aspects}

To answer the second research question that was what aspects of writing have the most correlation on students' grammar mastery, the mean of each aspect of writing was calculated in favor of getting the result. It is used to see the correlation of writing aspects and students' grammar mastery. The data are below:

Table 3.2 Analysis Result of Students' Writing Aspects and Grammar Mastery

\begin{tabular}{|c|c|c|c|}
\hline \multicolumn{4}{|c|}{ Correlations } \\
\hline & & Content & Grammar \\
\hline \multirow[t]{3}{*}{ Content } & Pearson Correlation & 1 &, $534^{* *}$ \\
\hline & Sig. (2-tailed) & &, 000 \\
\hline & $\mathrm{N}$ & 40 & 40 \\
\hline \multirow[t]{3}{*}{ Grammar } & Pearson Correlation &, $534^{* *}$ & 1 \\
\hline & Sig. (2-tailed) &, 000 & \\
\hline & $\mathrm{N}$ & 40 & 40 \\
\hline
\end{tabular}




\begin{tabular}{|c|c|c|c|}
\hline \multicolumn{4}{|c|}{ Correlations } \\
\hline & & Organization & Grammar \\
\hline \multirow[t]{3}{*}{ Organization } & Pearson Correlation & 1 & $539^{* *}$ \\
\hline & Sig. (2-tailed) & &, 000 \\
\hline & $\mathrm{N}$ & 40 & 40 \\
\hline \multirow[t]{3}{*}{ Grammar } & Pearson Correlation &, $539^{* *}$ & 1 \\
\hline & Sig. (2-tailed) &, 000 & \\
\hline & $\mathrm{N}$ & 40 & 40 \\
\hline
\end{tabular}

\begin{tabular}{|c|c|c|c|}
\hline \multicolumn{4}{|c|}{ Correlations } \\
\hline & & Vocabulary & Grammar \\
\hline \multirow[t]{3}{*}{ Vocabulary } & Pearson Correlation & 1 &, $560^{* * *}$ \\
\hline & Sig. (2-tailed) & &, 000 \\
\hline & $\mathrm{N}$ & 40 & 40 \\
\hline \multirow[t]{3}{*}{ Grammar } & Pearson Correlation &, $560^{* *}$ & 1 \\
\hline & Sig. (2-tailed) & 000 & \\
\hline & $\mathrm{N}$ & 40 & 40 \\
\hline
\end{tabular}

\begin{tabular}{|c|c|c|c|}
\hline \multicolumn{4}{|c|}{ Correlations } \\
\hline & & Language Use & Grammar \\
\hline \multirow[t]{3}{*}{ Language Use } & Pearson Correlation & 1 &, $603^{* *}$ \\
\hline & Sig. (2-tailed) & & ,000 \\
\hline & $\mathrm{N}$ & 40 & 40 \\
\hline \multirow[t]{3}{*}{ Grammar } & Pearson Correlation & $603^{* *}$ & 1 \\
\hline & Sig. (2-tailed) & ,000 & \\
\hline & $\mathrm{N}$ & 40 & 40 \\
\hline
\end{tabular}

\begin{tabular}{|c|c|c|c|}
\hline \multicolumn{4}{|c|}{ Correlations } \\
\hline & & Mechanics & Grammar \\
\hline \multirow[t]{3}{*}{ Mechanics } & Pearson Correlation & 1 &, $531^{* *}$ \\
\hline & Sig. (2-tailed) & &, 000 \\
\hline & $\mathrm{N}$ & 40 & 40 \\
\hline \multirow[t]{3}{*}{ Grammar } & Pearson Correlation &, $531^{* *}$ & 1 \\
\hline & Sig. (2-tailed) &, 000 & \\
\hline & $\mathrm{N}$ & 40 & 40 \\
\hline
\end{tabular}

From table 3.2, it can be assumed that from five writing aspects which are content, organization, vocabulary, language use, and mechanics. Language use was the aspect that most correlated with the students' grammar mastery by having the number of significant 0.603 . It can be concluded that language use was the aspect of writing that most correlated with students' grammar mastery. In conclusion, the answer to second research question was language use. 


\section{Discussion}

In this research, the researcher had collected the data by using two instruments. The first was grammar test that given to all students as participants in this research. They asked to answer the questions that given by the researcher through Google Form. This test used to know the students' grammar mastery. The second instrument was writing descriptive text. This test was conducted after the grammar test. In this discussion the researcher intended to present the result from the analysis of the findings. The analysis has been accomplished in order to answer the research problem.

Moreover, it was found that the coefficient correlation between students' grammar mastery and their writing ability was 0.730 . It can be concluded that there was positive correlation both two variables in high correlation. As the researcher explained before, if students had high grammar mastery, it would have an impact or influence on their writing especially in descriptive text. Moreover, students could also fail in writing if their grammar mastery is poor. In short, the increase in students' grammar was followed by the improvement of writing skills. Viet (1989) says that the knowledge of the structure can also be a tool to analyze our writing. When students master in understanding grammar, they also have a good ability in writing, because they know how to arrange the sentences into good texts that are understandable and meaningful. This factor implies that the students' activity and frequency in mastery of grammar provide a useful contribution to increase their achievement in writing descriptive texts. Furthermore, Istiqomah (2014) states that as one of the components in writing, grammar plays an important role in writing and clearly influences students' writing because the better students' grammar mastery, the better their writing. Some people may be good at writing descriptive text with lots of good ideas to express but if they don't have knowledge of grammar, they will have difficulty communicating those ideas to others.

Most studies have revealed a positive correlation between grammar and students' writing ability. A research was conducted by Putri (2018), Widya and Wahyuni (2018), and Putri et al. (2016). The result of those studies showed that the students' grammar mastery affected their enhancement in writing English. It means that there is a significant relationship between grammar mastery and writing ability. However, there is difference those studies and this research. The researcher investigated which aspect was the most correlated among aspects of writing. In addition, the researcher did the research via online.

There are some criteria in writing such as content, organization, vocabulary, language use, and mechanics. Language use is the most important aspect in writing which has the highest correlation with students' grammar mastery by having a significance number was 0.603 . Language use is a communicative meaning of language. It can be connected to usage, which relates to the rules for creating language and the structures we use to be meaningful (Klimova, 2011). According to Jacobs (1981) language use refers to the correct use of grammatical forms and syntactic patterns. It can be seen from the well-formed sentence construction because this can also affect the comprehensibility of a text. Furthermore, Klimova (2011) indicates that in the aspects of writing, particularly the language use, conforms to the needs of an ESL learner. Therefore, the most frequent errors for second language learners are the use of articles, word order, tenses and prepositions. However, it is common for students feel uneasy when they write because they have to express their ideas in foreign language. Although they have some problems in writing, with continuous practice, many mistakes can be avoided and can improve their writing skills as well (Lodge, 2012). 
From the explanation above, it can be concluded that language use and grammar are aspects that students must be mastered in writing because the two variables have the highest correlation. By using proper language use or grammar in writing, it will be created good communication.

\section{CONCLUSIONS AND SUGGESTIONS}

\section{Conclusion}

According to the data analysis and discussion, the researcher concludes that there is a positive correlation between students' grammar mastery and writing ability with the value of Pearson correlation is 0.703 , Sig. $=0.000$ which means lower than level of significant 0.05 . It indicated that there was a significant correlation between students' grammar mastery and writing ability. It means that when the students have good grammar mastery, they will have good achievement in writing. Meanwhile, students who get bad score in grammar, they will get poor in writing as well. Therefore, language use is the aspect of writing with the value of correlation is 0.603 , Sig. $=0.000$ which influences most of the students because the students should know how to arrange the sentences into an understandable and meaningful text.

\section{Suggestion}

After conducting the research, the author recommended several suggestions for both English teacher and further research. Firstly, the teacher should explain more about grammar before teaching about writing. The way they explain, it determines how the students' understand about the grammar. The teachers have important role in helping and facilitating the students to learn grammar well, so the students' writing ability will increase. Besides, the teacher should explain more to the students that there are some criteria to asses writing subject in order to the students are not only focus on grammatical aspects in writing but also learn more how to organize the text well by considering the content, organization, vocabulary, and also mechanics.

Furthermore, for the future researcher that not only grammar can influence students' writing, vocabulary mastery can also affect students to express their ideas in writing. It can be seen from the results of the correlation between grammar and vocabulary. Therefore, the researcher suggests other researchers to conduct other studies on different variables.

\section{REFERENCES}

Adhiyatma, B., \& Jamiluddin, N. (2015). The correlation between students' mastery of grammar and writing ability of the tenth grade. E-Journal of English Language Teaching Society (ELTS), 3(2).

Alameddine, M. M., \& Mirza, H. S. (2016). Teaching academic writing for advanced level grade 10 English. Procedia-Social and behavioral Sciences, 232, 209-216.

Andini, Y., Handriana, \& Delfi, S. (2017). The correlation between grammar mastery and reading comprehension of the second grade students of SMPN 12 Pekanbaru. Jurnal Online Mahasiswa Fakultas Keguruan dan Ilmu Pendidikan Universitas Riau, 1-10.

Brown, H. D. (1994). Teaching English as a foreign language second edition. Routledge.

Etfita, F. (2019). The correlation between students' grammar mastery and news writing ability. $A L-$ ISLAH: Jurnal Pendidikan, 11(1), 58-70. 
Fatemi, M. A. (2008). The relationship between writing competence, language proficiency and grammartical errors in the writing of Iranian tefl sophomores. [Doctoral dissertation, Universiti Sains Malaysia].

Gerot, L., \& Wignell, P. (1994). Making sense of functional grammar. Antipodean Educational Enterprises (AEE).

Istiqomah, S. (2014). Correlation between grammar mastery and descriptive writing ability. U-JET, $3(4)$.

Jacobs, H., Zingraf, S., Wormuth, D., Hartfiel, V., \& Hughey, J. (1981). Testing ESL compostion: a practical approach. Newbury House.

Klimova, B. F. (2011). Evaluating writing in English as second language. Procedia-Social and Behavioral Sciences, 28, 390-394.

Klimova, B. F. (2012). The importance of writing. Paripex - Indian Journal of Research , 9-11.

Lodge, D. (2012). The practice of writing. Random House.

Putri, A. T. (2018). The correlation between students' grammar mastery and their writing ability on descriptive paragraph at the tenth grade students of SMAN 2 Tapung. [Doctoral dissertation, Universitas Islam Negeri Sultan Syarif Kasim Riau].

Putri, Z., Silvianti, T. M., \& Achmad, D. (2016). The correlation between grammar mastery and writing ability. Proceedings of EEIC, 1(1), 217-222.

Richards, J. C., \& Renandya, W. A. (2002). Methodology in language teaching: an anthology of current practice. Cambridge.

Septiani, R. (2014). The correlation between grammar mastery and writing ability. Unpublished master's thesis at Universitas Islam Negeri Syarif Hidatullah.

Viet, R. (1989). Discovering English Grammar. Houghton Miftlin Company.

Widya, S. O., \& Wahyuni, I. (2018). The correlation between grammar mastery and writing thesis proposal at STKIP YDB Lubuk Alung. Jurnal Arbitrer, 75. 